\title{
8-isoprostane as the main marker of oxidative stress
}

\author{
N. M. Herasymchuk \\ Kharkiv National Medical University, Ukraine
}

The purpose - is to generalize the data of experimental and clinical studies which have established that the basis of main metabolic processes in humans are redox reactions. Among them, free-radical reactions, leading to the formation of peroxide compounds, play a special role. Thus, it is important to determine the parameters of oxidative stress, its intensity that is necessary for an adequate assessment of the body compensatory capabilities, the prognosis of the disease course and the effectiveness of the treatment received.

Material and methods. The article describes the definition of the notion of oxidative stress, lists the most important oxidants and the mechanisms of their damaging effects. The role of oxidative stress in a number of cardiovascular, pulmonary and neurological diseases pathogenesis has been discussed, and oxidative processes activation during oocyte maturation in the follicular fluid has been shown. Isoprostanes is a group of prostaglandin isomers which was discovered not long ago. The author of this article shows the metabolism of arachidonic acid as the most widespread and important precursor of eicosanoids, whose family includes isoprostanes. Isoprostanes appear in tissues and blood plasma as a consequence of membrane oxidative degradation, reflecting the change in the membranes integrity and fluidity under OS conditions. They are present in biological fluids, such as urine, blood, cerebrospinal fluid, and in exhaled air under normal conditions, increasing as OS occurs. 8-isoprostane is isomeric to prostaglandin F2 allowing to estimate the level of free radicals production with a sufficient degree of accuracy, reliability and reproduction of the study results and its amount is directly related to the level of free radicals formed.

Conclusions. The results of previous studies have shown that the determination of 8-iso-PgF2 $\alpha$ level serves as the gold standard for determining the activity of oxidative stress in persons with the diseases described, as well as in patients with diabetes mellitus, obesity, hypercholesterolemia and in smokers.

\section{8-ізопростан як основний маркер оксидативного стресу}

\section{Н. М. Герасимчук}

Мета роботи - узагальнення даних експериментальних і клінічних досліджень, якими встановлено, що в основі провідних метаболічних процесів людини лежать окислювально-відновні реакції. Серед них особливу роль відіграють вільнорадикальні реакції, що призводять до утворення перекисних сполук. Отже, актуальним є визначення параметрів оксидативного стресу, його інтенсивності, необхідної для адекватного оцінювання компенсаторних можливостей організму, прогнозу перебігу захворювання та ефективності лікування.

Матеріали та методи. Наведені визначення поняття оксидативний стрес, названі найважливіші оксиданти та механізми їхньої шкідливої дії. Обговорено роль оксидативного стресу в патогенезі низки серцево-судинних, легеневих і неврологічних захворювань, а також показана активація окислювальних процесів при дозріванні яйцеклітини у фолікулярній рідині. Ізопростани - нещодавно виявлена група ізомерів простагландинів. Показаний метаболізм арахідонової кислоти як найпоширенішого та найважливішого попередника ейкозаноїдів, до сімейства яких належать ізопростани. Ізопростани з'являються у тканинах і плазмі як наслідок окисної деградації мембран, показуючи зміну цілісності та плинності мембран під дією оксидативного стресу. Вони є в біологічних рідинах (сеча, кров, спинно-мозкова рідина) і в повітрі, що видихається, в нормальних умовах і підвищуються при оксидативному стресі. 8-ізопростан ізомерний простагландину F2, що дає змогу з достатнім ступенем точності, вірогідності та відтворення результатів дослідження оцінити рівень продукції вільних радикалів, і його кількість прямо пропорційна рівню утворених вільних радикалів.

Висновки. Результати попередніх досліджень показують, що встановлення рівня 8-iso-PgF2a (8-ізопростана) є золотим стандартом для визначення активності оксидативного стресу в осіб із названими захворюваннями, а також в обстежених осіб, які хворі на цукровий діабет, ожиріння, гіперхолестеринемію, в курців.

\section{8-изопростан как основной маркер оксидативного стресса}

\section{Н. Н. Герасимчук}

Цель работы - обобщение данных экспериментальных и клинических исследований, которыми установлено, что в основе ведущих метаболических процессов человека лежат окислительно-восстановительные реакции. Среди них особую роль играют свободнорадикальные реакции, ведущие к образованию перекисных соединений. Таким образом, актуально определение параметров оксидативного стресса, его интенсивности, необходимой для адекватной оценки компенсаторных возможностей организма, прогноза течения заболевания и эффективности лечения.

Материалы и методы. Представлено определение понятия оксидативный стресс, перечислены важнейшие оксиданты и механизмы их повреждающего действия. Обсуждена роль оксидативного стресса в патогенезе ряда сердечно-сосудистых, легочных и неврологических заболеваний, а также показана активация окислительных процессов при дозревании яйцеклетки в фолликулярной жидкости. Изопростаны - недавно обнаруженная группа изомеров простагландинов. Показан метаболизм арахидоновой кислоты как наиболее широко распространенного и важного предшественника эйкозаноидов,

Key words: oxidative stress, arachidonic acid, cardiovascular diseases, chronic obstructive pulmonary disease, diabetes mellitus, glomerulonephritis, female infertility.

\section{Zaporozhye} medical journal 2018; 20 (6), 853-859 DOI: 10.14739/2310-1210 2018.6.146780

E-mail: nino.gerasimchuk@ gmail.com

Кнючові слова: ОксиАативний стрес, арахідонова кислота, серцево-судинні захворювання, хронічне обструктивне захворювання мегень, цукровий діабет, гломерулонефрит, жіноче безпиіаяя.

\section{Запорізький} медичний журнал. - 2018. -

T. 20, № 6(111). C. 853-859 
Запорожский медицинский журнал. - 2018. -

T. 20, № 6(111). C. 853-859

к семейству которых и относятся изопростаны. Изопростаны появляются в тканях и плазме как следствие окислительной деградации мембран, отражая изменение целостности и текучести мембран под действием оксидативного стресса. Они присутствуют в биологических жидкостях (моча, кровь, спинно-мозговая жидкость) и в выдыхаемом воздухе в нормальных условиях и повышаются при оксидативном стрессе. 8-изопростан изомерный простагландину F2, позволяющий с достаточной степенью точности, достоверности и воспроизведения результатов исследования оценить уровень продукции свободных радикалов, и его количество прямо пропорционально уровню образованных свободных радикалов.

Выводы. Результаты предыдущих исследований показывают, что установление уровня 8-iso-PgF2a (8-изопростана) - золотой стандарт для определения активности оксидативного стресса у лиц с описанными заболеваниями, а также у больных сахарным диабетом, ожирением, гиперхолестеринемией, у курильщиков.

\section{Introduction}

According to the theory of free radical (peroxide) oxidation, formulated by A. N. Bach, the oxidation of an organic molecule by oxygen proceeds according to the principle of a chain mechanism. The initiators of oxidation are always free radicals - particles having an unpaired electron and possessing a much greater reactivity capacity with respect to their non-radical analogs. Many free radicals are cytotoxic and lead to the development of pathological conditions.

All the functionally important free radicals (FR), which are formed in the human body, contain oxygen. There are a number of normal metabolic processes byproducts with oxidative properties in the cell and the most important among them are so-called "reactive oxygen species" (ROS), which include the superoxide radical $\left(\mathrm{O}_{2}^{-}\right)$, hydroxyl radical $(\mathrm{OH}-)$, nitric oxide ( $\left.\mathrm{NO}^{-}\right)$, peroxynitrite (ONOO-), hydrogen peroxide $\left(\mathrm{H}_{2} \mathrm{O}_{2}\right)$, hypochloric acid $(\mathrm{HOCl})$ [1].

It is noted that the main forms of ROS are primarily normal components of cellular metabolism and perform the most important regulatory and metabolic functions in the body. Free radical reactions are necessary for the formation of many vital enzymes, as well as for the normal function of the immune system and its components (neutrophils, macrophages, etc.). They are absolutely necessary for the activation of many transcription factors involved in the genes expression; they carry out the transduction of hormonal and cellular signals and regulate the processes of bioenergetics, oxidation of xenobiotics, antimicrobial defense, and cell division. Free radical processes underlying the synthesis of many biologically active substances, such as leukotrienes, purine deoxyribonucleotides, uric acid, macroergic compounds, play an important role in regulatory processes. Sharp fluctuations of their concentration in cells and tissues can cause many pathological conditions in the body, the most significant of them are: activation of proliferation genes, apoptosis genes, cytokine expression, DNA damage, cytotoxicity, which in turn increases the production of oxidants [1].

At the present stage, the term «oxidative stress» (OS) means a state in which the amount of FR formed in the body is significantly higher than the activity of endogenous antioxidant systems that ensure their elimination. Oxidative aggression of $\mathrm{FR}$ is restrained by a powerful antioxidant system. Imbalance may be resulted from a lack of antioxidant defense system (ADS) caused by impaired production or distribution of antioxidants (AO) or an excess of ROS. OS is a common pathway for vascular endothelium damage.

Violation of the balance between synthesis and elimination of ROS, such as superoxide anion (O2-) and hydrogen peroxide $\left(\mathrm{H}_{2} \mathrm{O}_{2}\right)$, affects the homeostasis of cellular oxidative stress, plays an important role in the development of arterial hypertension (AH). Uncontrolled generation of ROS and their derivatives causes damage of proteins, nucleic acids, enzymes, biomembranes and ultimately leads to the pathological conditions development. OS leads to damage of the most important polymers - nucleic acids, proteins, lipids and cell mutations development, which can lead to cell death or their malignant degeneration [1].

Direct determination of the oxidants level in vivo is almost impossible, since these compounds are extremely reactive and, therefore, short-lived molecules. Ideal OS markers are lipid oxidation products, carbohydrates, proteins and nucleic acids, whose lifespan ranges from several hours to several weeks. One of the most specific biological markers, allowing to estimate the level of FR production with a sufficient degree of accuracy, reliability and reproduction of the study results, is 8-iso- $\mathrm{PgF} 2 \alpha$ (8-isoprostane, 15-F (2t) -IsoP, iPF $2 \alpha-I I I)$. The determination of 8-iso-PgF2 $\alpha$ level serves as the gold standard for oxidative stress in vivo [3]. The kit is intended for the quantitative determination of 8-isoprostane in specimens of plasma, serum, urine, supernatants of cell cultures and other biological fluids using the competitive immune enzyme assay.

Metabolism of arachidonic acid as the most widespread and important precursor of eicosanoids

Initially, isoprostanes were considered as biologically inactive products of lipid peroxidation the level of which in cells and tissues positively correlates with the level of FR that catalyze the process of non-enzymatic lipid peroxidation. The importance of isoprostanes in biology and medicine was discovered in 1990 [2].

8-isoprostane is a product of metabolism in reactions of arachidonic acid peroxidation, isomeric to prostaglandin F2 and its amount is directly proportional to the level of the formed FR. This substance belongs to the family of eicosanoids, the formation of which occurs during non-enzymatic (free radical) oxidation of phospholipids of cellular biomembranes [4]. This process does not depend on the enzymatic activity of cyclooxygenase catalyzing the conversion of arachidonic acid into prostaglandins. Eicosanoids, metabolites of arachidonic acid, are inflammatory mediators responsible for smooth muscle contraction, vasoconstriction / vasodilation, increased vascular permeability, hypersecretion of mucus, cough and inflammatory cell migration. These include prostaglandins, thromboxane, isoprostanes and leukotrienes (LT). This is a very large family of highly active compounds with an unusually wide spectrum of biological effects. In this connection, eicosanoids, inhibitors of their receptors and synthesis enzymes, as well as their lipid precursors contained in plants and some fish species, have a high therapeutic potential. Due to their short half-life, which ranges from seconds to minutes, special delivery systems or the synthesis of their stable analogs are required for clinical use. 
Arachidonic acid is the most widely spread and probably the most important precursor of eicosanoids. Arachidonic acid is a 20-carbon (C20) fatty acid containing four double bonds. For the synthesis of eicosanoids, first it is necessary to release or mobilize arachidonic acid from membrane phospholipids under the action of one or more types of phospholipase $A_{2}\left(P L A_{2}\right)$ enzymes. At least three phospholipases can participate in the formation of arachidonic acid from membrane lipids: cardiac PLA ${ }_{2}\left(\mathrm{CPLA}_{2}\right)$, cytosolic (cytoplasmic) and secretory.

To activate the first form, ionized calcium is not required. The second and third enzyme isoforms are calcium-dependent. Basically, they are involved in the process of arachidonic acid releasing. In addition to these mechanisms, arachidonic acid can also be released by the combined action of phospholipase $\mathrm{C}$ and diglyceride lipase. These lipase pathways are blocked by steroidal anti-inflammatory drugs. After mobilization, arachidonic acid undergoes oxygenation in four different ways: cyclooxygenase, lipoxygenase, P-450 epoxygenase and isoprostanic.

The isoprostanic pathway of arachidonic acid metabolism, another potentially important pathway for the metabolism of arachidonic acid, leads to the formation of isoprostanes. Isoprostanes are prostaglandin stereoisomers. Since prostaglandins have many asymmetric centers, they have a large number of potential stereoisomers. Prostaglandin synthetase (cyclooxygenase) does not participate in the formation of isoprostanes, therefore, aspirin and other non-steroidal cyclooxygenase inhibitors do not affect the isoprostanic pathway. The main mechanism of epimerization is the peroxidation of arachidonic acid by FR. It occurs at a time when arachidonic acid is still in the esterified form in membrane phospholipids. Thus, unlike prostaglandins, these stereoisomers are «deposited» in membranes. Isoprostanes appear in tissues and plasma as a consequence of oxidative membrane degradation, reflecting the change in the integrity and fluidity of membranes due to OS influence. They are present in biological fluids, such as urine, blood, cerebrospinal fluid, and in exhaled air under normal conditions, increasing as OS occurs [1].

The level of 8-isoprostane allows assessing OS and antioxidant defense. It is also a reliable indicator of the lipid-containing samples (serum, plasma, cellular specimens) integrity. Its level increases with the age in healthy individuals. The importance of the isoprostanic pathway is associated with a relatively large number of these products (there are 10 times more of them in blood and urine than prostaglandins formed by the cyclooxygenase pathway), as well as with their pronounced vasoconstrictive effect on renal and other vessels. It is assumed that isoprostanes play a significant role in the development of hepatorenal syndrome.

Concentration of 8-isoprostane in various diseases of internal organs

8-iso-PgF2 $\alpha$ is a stimulant for the proliferation of vascular smooth muscle and endothelial cells, strongly enhances vasoconstrictor responses of renal and pulmonary vessels, a stimulator of collagen hyperproduction in the hepatic fibrosis model, a mediator of hepatorenal syndrome and oxygen toxicity in the lungs, and an inhibitor of platelet aggregation.

8-isoprostane reflects the cellular effects of OS and, consequently, the airways inflammatory process. In recent years, there has been an increasing interest in lung research with non-invasive methods, including the measurement of biomarkers in exhaled air and exhaled breath condensate (EBC) $[5,6]$. These methods are safe, do not affect the lung function and the level of exhaled mediators [5], which makes them one of the epidemiological methods for pathological processes examination (OS and inflammation) in the study of respiratory diseases.

The concentration of 8-isoprostane in EBC was increased in patients with remission of chronic obstructive pulmonary disease (COPD) compared with healthy non-smoking subjects. Also, the level of 8-isoprostane in $\mathrm{EBC}$ was increased in healthy smokers and in patients with exacerbation of COPD. P. Montuschi et al. [5,7] showed that the values of 8-isoprostane in patients with COPD, both smokers and non-smokers, are 1.8 times higher than in healthy smokers. In healthy non-smokers, the concentration of this compound is 2.2 times lower than in healthy smokers. There were no correlations between the level of 8-isoprostane and the forced expiratory volume in one second (FEV1) value, smoking history, the cellular composition of sputum, or the severity of dyspnea in COPD patients [8]. However, in patients with a mild degree of bronchial asthma, an increase in the concentration of 8-isoprostane in EBC was found to be 2-fold compared to healthy people, and in severe cases, its level was 3 times higher than in patients with mild bronchial asthma, regardless of inhaled glucocorticosteroid treatment. After the treatment, its concentration decreased [8].

In children with mild asthma without the use of steroid inhalers, the level of 8 -isoprostane was $9.3 \mathrm{pg} / \mathrm{ml}$ vs 3.8 $\mathrm{pg} / \mathrm{ml}, \mathrm{P}<0.01$; in children received inhaled steroids, the level of 8-isoprostane was $6.7 \mathrm{pg} / \mathrm{ml}$ vs $3.8 \mathrm{pg} / \mathrm{ml}, P<0.01$ in comparison with the group of healthy children. Prior to treatment with prednisolone, 8-isoprostane concentrations were higher in children with bronchial asthma $(12.0 \mathrm{pg} / \mathrm{ml}$, $P<0.001)$ than in healthy children $(2.6 \mathrm{pg} / \mathrm{ml}, \mathrm{P}<0.001)$. After the treatment with prednisolone, there was a significant decrease in the concentration of 8-isoprostane to $8.4 \mathrm{pg} / \mathrm{ml}$, $P=0.04$, but the level of the latter was higher than in healthy children $(P<0.001)$ [9]. The level of 8-isoprostane did not correlate with the disease duration and the dose of steroids. It follows that steroid therapy does not correct OS in children with bronchial asthma, and, possibly, antioxidant therapy will be useful for such patients.

Patients with bronchial asthma and concomitant gastroesophageal reflux (GER) had a higher level of 8-isoprostane than without GER, and after treatment with proton pump inhibitors, the level of 8-isoprostane decreased along with the improvement in the condition.

The level of 8-isoprostane in EBC in patients with cystic fibrosis was 3 times higher in comparison with normal subjects $42.7 \pm 4.5 \mathrm{pg} / \mathrm{ml}$ vs $15.2 \pm 1.7 \mathrm{pg} / \mathrm{ml}, \mathrm{P}<0.005$, $95 \%$ confidence interval $(\mathrm{Cl}) 14.6$ to 40.9$)$ is negatively correlated with FEV1 $(r=-0.61, P<0.005)[10]$.

Isola N. et al. showed that the 8-isoprostane content in EBC of patients with idiopathic fibrosing alveolitis was significantly higher and correlated with the severity of the disease. The data presented indicate that measuring the concentration of 8-isoprostane in EBC may be another marker of OS in lung diseases.

A number of authors note that $\mathrm{OS}$ and lipid peroxidation mean a lot in neurodegenerative diseases such as Alzheimer's disease, Huntington's chorea, multiple sclerosis, 


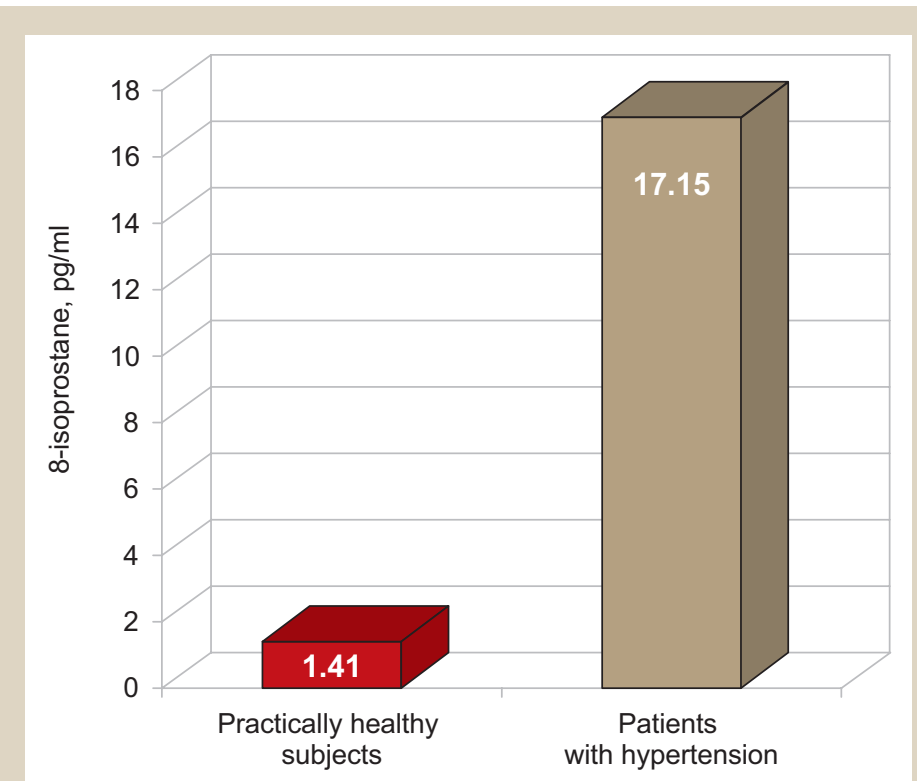

Fig. 1. Blood serum of patients with hypertension compared with practically healthy subjects.

Creutzfeldt-Jakob disease, Down's syndrome (DS). It has been proved that FR affect brain lipids, carbohydrates, proteins and DNA, participate in the death of neurons in neurodegenerative disorders, and affect many clinical features of DS $[11,12]$.

In the modern literature there are data on the increase in the level of 8-isoprostane in scleroderma, alcoholic liver disease [13], coronary heart disease, arterial hypertension (AH) [14] and progression of heart failure [15].

The level of 8-isoprostane directly correlates with the functional class of chronic heart failure with a strong linear dependence [15]. A high level of matrix metalloproteinase (MMP) can accelerate pathological ventricular remodeling and increase the severity of chronic heart failure (CHF). K. Kameda et al. showed the effect of OS on MMP activity in the patients. The authors measured the concentration of 8-iso-PGF2 $\alpha$ and pericardial levels of MMP activity, indicating their levels in tissues, in patients with coronary heart disease who underwent coronary artery bypass graft surgery (CABG). Immediately after a small pericardial incision, the undiluted pericardial fluid was obtained. MMP-2 and MMP-9 activity positively correlated with the pericardial level of 8-iso-PGF2 $\alpha$ (MMP-2, $r=0.55, P<0.0001$, MMP-9, $r=0.52, P<0.001)$. Moreover, left ventricular end-diastolic volume index (LVEDVI) also positively correlated with the pericardial level of 8-iso-PGF2 $\alpha(r=0.34, P<0.05)$ and not with the left ventricular end-systolic volume index (LVESVI) or the left ventricular ejection fraction (LVEF) [16].

We have previously found an increase in the content of 8-iso-PgF2 $\alpha$ in the blood serum of patients with hypertension compared with practically healthy subjects: $17.15 \pm 3.12 \mathrm{pg} / \mathrm{ml}$ and $1.41 \pm 0.81 \mathrm{pg} / \mathrm{ml}$, respectively, where $(P<0.05)$. In this case, the level of 8 -iso-PgF2 $\alpha$ in the presence of hypertension was 12.16 times higher than that of the control group (Fig. 1).

When comparing the content of 8-isoprostane in subjects with hypertension, depending on the level of blood pressure, it was revealed that as the $\mathrm{AH}$ progressed, the concentration of 8-isoprostane in the blood serum increased: by 3.2, 7.1 and 18.4 times compared with the controls (the 1st, 2nd and 3rd degree, respectively). The obtained data testify not only to an increase in the activity of 8-isoprostane in the serum, but also about state of OS presence in hypertension, which is more pronounced in persons with the 3 rd degree $\mathrm{AH}$ with obesity. In patients with hypertension who have obesity, the content of 8-isoprostane increases by 14.9 times in comparison with those in the control group. The dynamics of the studied indicator average values in the course of combined antihypertensive therapy decreases. The authors also noted that the level of 8-isoprostane does not depend on the duration of $\mathrm{AH}$, but only on the degree of increasing blood pressure (BP) [17-19].

It was proved that the level of 8-isoprostane is increased in patients with acute myocardial infarction compared to patients with stable angina pectoris and patients without significant changes in coronary vessels and may be a marker of atherosclerosis development [20].

At present, the number of people suffering from obesity is still growing. Obesity is one of the reasons of atherosclerotic cardiovascular disease.

Keaney et al. determined the correlation between the body mass index (BMI) and 8-iso-PgF2 $\alpha$ levels in urine in nearly 3,000 participants in the Framingham Heart Study. The results have shown that there is a strong link between $\mathrm{BMI}$ and the levels of 8-iso-PgF2 $\alpha$ in urine [21]. Also Davi et al. in their study have found a correlation between 8-iso-PgF2 $\alpha$ and obesity. In this study, the authors also have noted that women with android obesity had higher levels of 8-iso-PgF2 $\alpha$ in the urine than women with gynoid obesity $(P<0.001)$. Moreover, other authors have noticed that a decrease in BMl leads to a decrease of 8-iso-PgF2 $\alpha$ level in the urine [22]. Urinary of 8-epi-PGF2 $\alpha$ was indexed to creatinine as $\mathrm{pg} / \mathrm{mg}$ creatinine.

G. Desideri, C. Ferry have found a significant increase in the level of 8-isoprostane in obese individuals compared with persons without it and after 16 weeks of intervention measures involving calorie restriction and leading to weight loss, the level of 8-isoprostane decreased with a parallel decrease in the BMI [23].

A significant increase in the 8-isoprostane level has been observed in a number of situations, which are characterized by increased activity of oxidative processes, in particular during tobacco smoking, diabetes mellitus and hypercholesterolemia [14,24,25].

Morrow et al. studied the correlation between smoking status and levels of free 8-iso-PgF2 $\alpha$ in plasma. In an experimental study with 16 smokers and 8 non-smokers of the same age the levels of free 8-iso-PgF2 $\alpha$ in plasma of smokers' samples (166 $\pm 58 \mathrm{pmol} / \mathrm{l})$ were significantly higher $(P=0.02)$ than in non-smokers of the same age and $\operatorname{sex}(90 \pm 52 \mathrm{pmol} / \mathrm{l})$ [2].

Obata et al. did not find a correlation between the levels of 8-iso-PgF2 $\alpha$ and the age of smokers, the duration of smoking and the number of cigarettes smoked per day, but they found a weak negative correlation between urine isoprostane concentrations and the age of nonsmokers and the time since quitting in ex-smokers [26]. A strong positive correlation between levels of 8-iso-PgF2 $\alpha$ in urine and smoking status has also been detected by Keaney et al. $(P<0.0001)[21]$. 
An increase in the synthesis of lipid peroxidation in diabetes mellitus (DM) leads to an increase in 8-isoprostane, which in turn promotes the oxidation of arachidonic acid products that have a vasoconstrictive effect. Gopaul et al. [27] analyzed the levels of 8-iso-PgF2 $\alpha$ in non-insulin-dependent diabetes mellitus (NIDDM, type 2 diabetes) and compared them with these indices in healthy individuals. Plasma levels of 8-iso- PGF2 $\alpha$ in samples from individuals with diabetes $(n=39)$ were higher $(0.49-2.16 n M)$ than in the control group $(n=16)(0.02-0.63 n M)$.

Davi et al. [28] obtained similar results, but in the process of immunoreactive 8-iso-PGF2 a measurement in urine samples, because the collection of urine is non-invasive and isporostanes are very stable [29]. Levels of 8-iso-PGF2 $\alpha$ in urine of patients with NIDDM $(\mathrm{n}=62,419 \pm 208 \mathrm{pg} / \mathrm{mg}$ creatinine) were significantly higher $(P=0.0001)$ than in healthy age groups (208 $\pm 92 \mathrm{pg} / \mathrm{mg}$ creatinine).

The authors also studied the levels of 8-iso-PgF2 $\alpha$ in patients with insulin-dependent diabetes mellitus (IDDM, type 1 diabetes). Urinary 8-iso-PGF2a levels were also higher $(n=23.400-146 \mathrm{pg} / \mathrm{mg}$ creatinine $)$ in these patients compared with the control group (197 $\pm 69 \mathrm{pg} / \mathrm{mg}$ creatinine, $P=0.0001)$.

Davi et al. also noted that in children and adolescents with type 1 diabetes the level of 8-isoprostane is increased at an early stage of the disease and decreases as the disease progresses [30]. The indices of 8-isoprostane are greater in the group of patients with type 2 diabetes combined with non-alcoholic fatty liver disease (NAFLD) than without it and also in comparison to healthy individuals. A decrease in this index against the background of NAFLD initial manifestations therapy has been noted, which could serve as a prognostic favorable factor for diagnostics, prognosis of NAFLD and further studies for treatment regimens improvement. An increase in the level of 8-isoprostane, which is associated with an increase in the basic indices of protein and lipid metabolism, and a decrease in this indicator in patients with type 2 diabetes combined with NAFLD during treatment (including drugs affecting endothelial dysfunction in therapy scheme) characterize this parameter not only as a known indicator of OS, but also as a marker of atherogenesis [31].

G. Davi et al. showed that excretion of 8-iso-PgF2 $\alpha$ with the urine was significantly higher $(P<0.001)$ in patients with hypercholesterolemia than in age- and sex-matched control subjects $(473 \pm 305 \mathrm{pg} / \mathrm{ml}$ vs $208 \pm 95 \mathrm{pg} / \mathrm{mg}$ creatinine). Its excretion rate was directly proportional to the level of low density lipoprotein (LDL) cholesterol and was inversely proportional to the vitamin E content in LDL. The dose-dependent suppression of enhanced production of 8-iso-PgF2 $\alpha$ by vitamin E supplementation could promote the beneficial effects of antioxidant treatment [24].

Reilly et al. have studied the levels of isoprostanes in the urine of patients with homozygous familial hypercholesterolemia ( $\mathrm{HFH}$ ) and moderate hypercholesterolemia $(\mathrm{HC})$. There were no significant correlations between 8-iso-PgF2 $\alpha$ in urine and age, sex and history of lipid-lowering agents use in patients with $\mathrm{HFH}$ [25].

Ciuntu Angela presents the results of urinary concentration of 8-isoprostane determination in 50 children with different forms of primary glomerulonephritis. Children with a steroid-sensitive nephrotic syndrome (SSNS) had complete remission during the first 4 weeks, rarely during 8 weeks off corticosteroid therapy. Patients with steroid resistant nephrotic syndrome (SRNS) represented long-term proteinuria ( $3 \mathrm{~g} / \mathrm{d} \mathrm{L}$ up to $6-8$ weeks of treatment with prednisolone at a dose of $2 \mathrm{mg} / \mathrm{kg} / 24$ hours (maximum $60 \mathrm{mg} / 24 \mathrm{~h}$ ), followed by a pulse therapy with prednisolone at a dose of 20-30 $\mathrm{mg} / \mathrm{kg} / 24 \mathrm{~h} \mathrm{~N} 3$ (maximum $1 \mathrm{~g}$ for the course of treatment).

The concentration of 8-isoprostane in urine was 3.4 times higher in the group of patients with steroidresistant nephrotic syndrome (SRNS) in the phase of clinical manifestations (up to $129.28 \pm 8.80 \mathrm{ng} / \mathrm{mM}$ creatinine) and 1.5 times higher in patients with steroid-sensitive nephrotic syndrome (SSHNS) (up to $56.68 \pm 3.83 \mathrm{ng} / \mathrm{mM}$ creatinine), and in children with chronic glomerulonephritis (CGN) mixed type, the concentration of this indicator was 3.5 times higher (up to $131.71 \pm 13.15 \mathrm{ng} / \mathrm{mM}$ creatinine) in comparison with the group of healthy children (37.65 \pm $1.26 \mathrm{ng} / \mathrm{mM}$ creatinine). During the period of this disease remission the concentration of 8-isoprostane in the urine remained high. Hence, the determination of 8-isoprostane urinary concentration is an OS marker in patients with chronic kidney disease [32].

A number of authors determined the level of 8-isoprostane, as a marker of OS in women with infertility. Female infertility is an urgent problem of our time, which causes the development and necessity of improving additional reproductive technologies. The most effective of these is in vitro fertilization (IVF). The main and integral stage of IVF is controlled ovarian stimulation. This part can be characterized as key and challenging, because with the purpose of follicular pool formation, stimulation of the follicular cohort development and obtaining the maximum number of oocytes, the follicular apparatus is medicated. This is possible only under condition of preserved woman's reproductive potential, an ovarian reserve, an indicator that reflects the size of the resting follicle pool and the quality of the oocytes. According to recent research, oxidative processes are activated in the follicular fluid during oocyte maturation, and when superovulation is induced, the peroxide oxidation of lipids and proteins increases dozens of times.

There are powerful levers of antioxidant system in the body. One of the effective components of antioxidant defense is melatonin. Melatonin is a thymus hormone secreted at night and regulates a number of important central and peripheral functions. Shcherbina N. A., Gradil O. G. studied the content of melatonin and 8-isoprostane in the serum and follicular fluid against the background of controlled ovarian stimulation in 66 infertile patients who were divided into two equal in number groups. The control group consisted of 33 healthy women of reproductive age. It has been found that melatonin has a pronounced antioxidant effect, thereby increases the number of oocytes obtained from the bad responders, and 8-isoprostane is a reliable indicator of OS and the antioxidant system status in blood serum and follicular fluid. The level of 8-isoprostane in the follicular fluid was $363.00 \pm 64.38 \mathrm{pg} / \mathrm{ml}$ and 318.98 $\pm 83.17 \mathrm{pg} / \mathrm{ml}$, respectively, in the examined patients of two equal in number groups versus the 8-isoprostane value of $188.01 \pm 10.50 \mathrm{pg} / \mathrm{ml}$ in the control group. Its level had a strong inverse correlation with the level of melatonin and the number of oocytes obtained after controlled ovarian stimulation [33]. 
Alcohol and antioxidant status of patients with breast cancer $(B C)$

According to epidemiological studies, alcohol consumption correlates with the risk of breast cancer. However, the exact mechanisms of this connection are still being discussed. The Postmenopausal Women's Alcohol Study was designed to evaluate the effects of moderate alcohol consumption on the level of antioxidants and OS markers.

The study involved 53 postmenopausal women, who for a period of 8 weeks were prescribed a certain diet with one of the products: 15 or $30 \mathrm{~g}$ of alcohol per day or a placebo. The level of antioxidants, vitamin $E$ (alpha and gamma-tocopherol), selenium and vitamin $C$ was determined at the beginning and the end of the observation period. The level of $15-\mathrm{F}(2 \mathrm{t})$-IsoP isoprostane obtained as a result of peroxidation was also determined. This indicator serves as a marker of OS and conditions that promote carcinogenesis. After excluding the influence of body mass index and serum cholesterol level, a significant decrease in the level of alpha-tocopherol by $4.6 \%$ and an increase in the level of 8 -isoprostane by $4.9 \%$ in the group who took 30 grams of alcohol per day were revealed. The intake of alcohol had no effect on the other antioxidants level. As can be seen, even moderate alcohol consumption in postmenopausal women leads to an increase in the level of OS markers [34].

\section{Conclusions}

Thus, the determination of OS parameters and its intensity is necessary for an adequate assessment of the organism compensatory capabilities, the prognosis of the disease course and the effectiveness of the treatment received. 8-isoprostane can serve as a reliable marker of OS level in the body with various pathologies.

It is important that the determination of 8-isoprostane concentration is possible both by an invasive method in plasma or serum, in the follicular fluid, in the pericardial fluid and non-invasively in the condensate of exhaled air, in the urine. The latter can be often repeated and applied to children, including newborns, and patients with severe disease, when more invasive procedures are impossible.

Unfortunately, not every patient can be examined for determining the level of 8-isoprostane, as the main marker of OS due to its cost.

Despite active research into the assessment of balance between FR and the antioxidant defense system and the continuous search for new markers of redox reactions, the reasons needed to understand the correlation between OS and pathological processes in the body have not been fully revealed. Important medical-social and economic aspects of cardiovascular system, respiratory organs, kidney diseases, diabetes mellitus, obesity, hypercholesterolemia justify the prospectivity of studies of key links of the processes that form a universal pathophysiological picture and contribute to the improvement of pathogenetic approaches of modern drug therapy.

This is the basis for further study of this issue.

Conflicts of interest: author has no conflict of interest to declare. Конфлікт інтересів: віАсутній.
Information about author: Herasymchuk N. M., MD, PhD, Associate Professor of the Department of Propedeutics to Internal Medicine No 1, Fundamentals of Bioethics and Biosafety, Kharkiv National Medical University, Ukraine.

\section{Відомості про автора:}

Герасимчук Н. М., канА. меА. наук, Аоцент каф. пропедевтики внутрішньої медицини № 1, основ біоетики та біобезпеки, Харківський національний медичний університет, Україна.

\section{Сведения об авторе:}

Герасимчук Н. Н., канА. меА. наук, Аоцент

каф. пропеАевтики внутренней меАицины № 1, основ биоэтики и биобезопасности, Харьковский национальный медицинский университет, Украина.

Надійшла Ао реАакції / Received: 20.03.2018

Після Аоопрацювання / Revised: 12.04 .2018

Прийнято Ао Аруку / Accepted: 17.04.2018

\section{References}

[1] Kovalyova, O. N., Ashcheulova, T. V., Gerasimchuk, N. N., \& Safargalina-Kornilova, N. A. (2015). Rol' oksidativnogo stressa v stanovlenil i progressirovanii gipertonicheskoj bolezni [Role of oxidative stress in the formation and progression of hypertensive diseas]. Nauchnye vedomosti Belgorodskogo gosudarstvennogo universiteta. Medicina Farmaciya, 4(201), 29, 5-10. [in Russian].

[2] Czerska, M., Zieliński, M. \& Gromadzińska, J. (2016). Isoprostanes A novel major group of oxidative stress markers. International Journal of Occupational Medicine and Environmental Health, 29(2), 179-90. doi: 10.13075/ijomeh.1896.00596.

[3] Huiyong, Y. (2008). New techniques to detect oxidative stress markers: Mass spectrometry-based methods to detect isoprostanes as the gold standard for oxidative stress in vivo. Bio Factors, 34(2), 109-124 doi: 10.1002/biof.5520340203.

[4] Czerska, M., Mikołajewska, K., Zieliński, M., Gromadzińska, J., \& Wąsowicz, W. (2015). Today's oxidative stress markers. Medycyna Pracy, 66(3), 393-405. doi: 10.13075/mp.5893.00137.

[5] Montuschi, P. (2013). Measurement of Biomarkers of Oxidative Stress and Airway Inflammation in Exhaled Breath Condensate: Methodology and Potential Applications in Patients with COPD and Healthy Smokers. Volatile Biomarkers, 360-381. doi: 10.1016/B978-0-44462613-4.00019-2\}.

[6] Taylor, D. R. (2011). Using biomarkers in the assessment of airways disease. Journal of Allergy and Clinical Immunology, 128(5), 927-934. doi: 10.1016/j.jaci.2011.03.051.

[7] Antczak, A., Ciebiada, M., Pietras, T., Piotrowski, W., Kurmanowska, Z., \& Górski, P. (2012). Exhaled eicosanoids and biomarkers of oxidative stress in exacerbation of chronic obstructive pulmonary disease. Archives of Medical Science, 8(2), 277-85. doi: 10.5114/ aoms.2012.28555.

[8] Anaev, E. Kh., Anokhina, T. N., Kushaeva, M. E., \& Chuchalin, A. G. (2013). Neinvazivnye biomarkery khronicheskoj obstruktivnoj bolezni legkikh [Non invasive biomarkers of chronic obstructive pulmonary disease]. Pul'monologiya, 3, 97-104. [in Russian].

[9] Baraldi, E., Carraro, S., Alinovi, R., Pesci, A., Ghiro, L., Bodini, A., et al. (2003). Cysteinyl leukotrienes and 8-isoprostane in exhaled breath condensate of children with asthma exacerbations. Thorax, 58(6), 505-509.

[10] Montuschi, P., Kharitonov, S. A., Ciabattoni, G., Corradi, M., Van Rensen, L., Geddes, D. M., et al. (2000). Exhaled 8-isoprostane as a new non-invasive biomarker of oxidative stress in cystic fibrosis. Thorax, 55(3), 205-209. doi: [10.1136/thorax.55.3.205].

[11] Miller, E., Morel, A., Saso, L. \& Saluk J. (2014). Isoprostanes and Neuroprostanes as Biomarkers of Oxidative Stress in Neurodegenerative Diseases. Oxidative Medicine and Cellular Longevity, 2014, 572491. doi: $10.1155 / 2014 / 572491$.

[12] Chen, L. \& Liu, B. (2017). Relationships between Stress Granules, Oxidative Stress, and Neurodegenerative Disease. Oxidative Medicine and Cellular Longevity, 2017, 1-10. doi: 10.1155/2017/1809592.

[13] Souvignet, C., Cracowski, J. L., Stanke-Labesque, F. \& Bessard, G. (2000). Are Isoprostans a Clinical Marker for Antioxidant Drug Investigation. Fundamental \& Clinical Pharmacology, 14(1), 1-10.

[14] Ndisang, J. F., Vannacci, A., \& Rastogi S. (2014). Oxidative Stress and Inflammation in Obesity, Diabetes, Hypertension, and Related Cardiometabolic Complications. Oxidative Medicine and Cellular Longevity, 2014, 506948. doi: 10.1155/2014/506948. 
[15] Zaika, M. V., \& Kovalyova, O. N. (2006). 8-izoprostan, kak marker oksidativnogo stressa u pacientov s hronicheskoj serdechnoj nedostatochnost'ju [8-isoprostane as a marker of oxidative stress in patients with chronic heart failure]. Ukrainskyi kardiolohichnyi zhurnal, 4, 55-57. [in Russian].

[16] Kameda, K., Matsunaga, T., Abe, N., Hanada, H., Ishizaka, H., Ono, $H_{\text {. }}$, et al. (2003). Correlation of oxidative stress with activity of matrix metalloproteinase in patients with coronary artery disease. European Heart Journal, 24(24), 2180-2185. doi.org/10.1016/j.ehj.2003.09.022.

[17] Gerasimchuk, N. N., \& Kovalyova, O. N. (2007). Uroven' 8-izoprostana $v$ dinamike kombinirovannoj antigipertenzivnoj terapii u bol'nykh s izbytochnoj massoj tela [Plasma level 8-isoprostane in the dynamics of combined antihypertensive therapy in patients with excessive body mass]. Ukrainskyj terapevtychnyj zhurnal, 2, 26-31. [in Russian].

[18] Kovalyova, O. N., Ashcheulova, T. V. \& Gerasimchuk, N. N. (2015) Vzaimosvyaz immunnoj aktivacii i oksidativnogo stressa u bol'nykh gipertonicheskoj boleznyu i ikh korrekciya kombinirovannoj antigipertenzivnoj terapiej [Relationship of immune activation and oxidative stress in patients with hypertension and their correction combined antihypertensive therapy]. Nauchnye vedomosti Belgorodskogo gosudarstvennogo universiteta. Medicina Farmaciya, 16(213), 31, 52-59. [in Russian].

[19] Ashcheulova, T. \& Gerasimchuk, N. (2016). Relationships of oxidative stress and systemic inflammation markers depending on the degree and duration of hypertension. Visnyk of Dnipropetrovsk University. Biology, medicine, 7(2), 118-122. doi: https://doi.org/10.15421/021621.

[20] Elesber, A. A., Best P. J., Lennon R. J., \& Mathew, V. (2006). Plasma 8-iso-prostaglandin F2alpha, a marker of oxidative stress, is increased in patients with acute myocardial infarction. Free Radical Research, 40(4), 385-391. doi: 10.1080/10715760500539154.

[21] Keaney, J. F., Larson, M. G., Vasan, R. S., Wilson, P. W. F., Lipinska, I., Corey, D., et al. (2003). Obesity and systemic oxidative stress: Clinical correlates of oxidative stress in the Framingham Study. Arteriosclerosis, Thrombosis, and Vascular Biology, 23, 434-439. doi: 10.1161/01. ATV.0000058402.34138.11.

[22] Davì, G., Guagnano, M. T., Ciabattoni, G., Basili, S., Falco, A., Marinopiccoli, M., et al. (2002). Platelet activation in obese women. Role of inflammation and oxidant stress. The Journal of the American Medical Association., 288(16), 2008-2014. doi.org/10.1001/jama.288.16.2008.

[23] Decideri, G., \& Ferry, C. (2003). Effects of obesity and weight loss on soluble CD $40 \mathrm{~L}$ levels. The Journal of the American Medical Association, 289(14), 1781-1782. doi: 10.1001/jama.289.14.1781.

[24] Davi, G., Alessandrini, P., Mezzetti, A., Minotti, G., Bucciarelli, T., Costantini, F., et al. (1997). In vivo formation of 8-epi-PGF2 is increased in hypercholesterolemia. Arteriosclerosis, Thrombosis, and Vascular Biology, 17, 3230-3235. doi: 10.1161/01.ATV.17.11.3230\}.

[25] Reilly, M. P., Praticò, D., Delanty, N., Diminno, G., Tremoli, E., Rader, D., et al. (1998). Increased formation of distinct F2 isoprostanes in hypercholesterolemia. Circulation, 98, 2822-2828. doi.org/10.1161/01. cir.98.25.2822.

[26] Obata, T., Tomaru, K., Nagakura, T., Izumi, Y. \& Kawamoto, T. (2000). Smoking and oxidant stress: Assay of isoprostane in human urine by gas chromatography-mass spectrometry. Journal of Chromatography B: Biomedical Sciences and Applications, 746(1), 11-15. doi: 10.1016/ S0378-4347(00)00182-1.

[27] Gopaul, N. K., Anggard, E. E., Mallet, A. I., Betteridge, D. J., Wolff, S. P., \& Nouroo-Zadeh, J. (1995). Plasma 8-epi-PGF2a levels are elevated in individuals with non-insulin dependent diabetes mellitus. FEBS Letters, 368(2), 225-229. doi.org/10.1016/0014-5793(95)00649-t.

[28] Davì, G., Ciabattoni, G., Consoli, A., Mezzetti, A., Falco, A., Santarone, S., et al. (1999). In vivo formation of 8-iso-prostaglandin F2 $\alpha$ and platelet activation in diabetes mellitus: Effect of improved metabolic control and vitamin E supplementation. Circulation, 99(2), 224-229. doi.org/10.1161/01.cir.99.2.224.

[29] Cracowski, J. L., Durand, T., \& Bessard, G. (2002). Isoprostanes as a biomarker of lipid peroxidation in humans: physiology, pharmacology and clinical implications. Trends in Pharmacological Sciences, 23(8), 360-3. doi: 10.1016/S0165-6147(02)02053-9.

[30] Davì, G., Chiarelli, F., Santilli, F., Pomilio, M., Vigneri, S., Falco, A., et al. (2003). Enhanced lipid peroxidation and platelet activation in the early phase of type 1 diabetes mellitus: Role of interleukin-6 and disease duration. Circulation, 107, 3199-3203. doi: 10.1161/01. CIR.0000074205.17807.D0.

[31] Dorosh, E. G. \& Kravchun, N. A. (2013). Uroven' 8-izoprostaglandina i ego vzaimosvyaz' s metabolicheskimi pokazatelyami u bol'nykh sakharnym diabetom 2-go tipa v sochetanii s nealkogol'noj zhirovoj bolezn'yu pecheni [8-Iso-prostaglandin level and its relation to metabolic parameters in patients with type 2 diabetes mellitus in combination with non-alcoholic fatty liver disease]. Prakticheskaya medicina, akusherstvo, ginekologiya, e'ndokrinologiya, 7(76), 111-116. [in Russian].
[32] Ciuntu, A. (2016). Concentration of isoprostane-8 in the urine of children with glomerulonephritisIS. Iscience.in.ua. Aktual'nye nauchnye issledovaniya v sovremennom mire - iscience.in.ua, 12(20), 110-115.

[33] Scherbina, M., \& Gradil, O. (2014). Suchasni aspekty provedennia ovarial'noi stymuliatsii v umovakh okysliuvalnoho stresu [The modern aspects IVF the background of oxidative stress]. Naukovyi visnyk mizhnarodnoho humanitarnoho universytetu, 8, 31-34. [in Ukrainian].

[34] Hartman, T. J., Baer, D. J., Graham, L. B., Stone, W. L., Gunter, E. W., Parker, C. E., et al. (2005). Moderate alcohol consumption and levels of antioxidant vitamins and isoprostanes in postmenopausal women. European Journal of Clinical Nutrition, 59, 161-168. doi: 10.1038/ sj.ejcn.1602051. 